\title{
DIRASAH
}

Volume 3, Number 2, Agustus s2020

p-ISSN: 2615-0212 | e-ISSN: 2621-2838

https://ejournal.iaifa.ac.id/index.php/dirasah

\begin{tabular}{|c|c|c|}
\hline Accepted: & Revised: & Published: \\
April 2020 & Juni 2020 & Agustus 2020 \\
\hline
\end{tabular}

\section{Pembelajaran Kontekstual \\ Pada Mata Pelajaran Ilmu Pengetahuan Sosial(IPS)}

\author{
Noor Rofiq ${ }^{1}$, A. Rafiq ${ }^{2}$ dan Muhammad Agus Wardani ${ }^{3}$ \\ IAIN Salatiga, Salatiga, Indonesia \\ e-mail:1 rafikatina@gmail.com, ${ }^{2}$ rofikpasca@gmail.com, \\ 33guswardani84@gmail.com
}

\begin{abstract}
Overall the scope of IPS learning is the integration of individuals into their social environment. While the learning model is a learning strategy with a structured procedure or pattern that is used as a guide to achieving goals. Therefore, this study aims to describe the conceptual learning model that links real life examples in the integrative thematic approach to social studies subjects. The conceptual model is a learning model that applies in integrating the daily lives of students and then is used as a value material in learning. This study uses the library research method, by examining some of the literature on conceptual learning models that are applied into Social Sciences (IPS) subjects. So it can be said, the conceptual model is an innovation in the world of education, which is a form of development of the old model.
\end{abstract}

Keywords: learning model, conceptual, social studies 


\begin{abstract}
Abstaksi
Secara keseluruhan ruang lingkup pembelajaran ips merupakan integrasi individu terhadap lingkungan sosialnya. Sedangkan model pembelajaran merupakan startegi pembelajaran dengan prosedur atau pola tersetruktur yang digunakan sebagai pedoman untuk mencapai tujuan. Oleh karena itu, Penelitian ini bertujuan untuk mendeskripsikan model pembelajaran konseptual yang mengaitkan contoh kehidupan nyata dalam pendekatan tematik integrative pada mata pelajaran IPS. Model konseptual merupakan sebuah model pembelajran yang mengaplikasikan dalam mengintegrasikan kehidupan seharihari peserta didik kemudian dijadikan bahan nilai dalam pembelajaran. penelitian ini menggunakan metode library research, dengan menelaah beberapa literatur mengenai model pembelajaran konseptual yang diaplikasikan kedalam mata pelajaran Ilmu Pengetahuan Sosial (IPS). Sehingga dapat dikatakan, model konseptual merupakan inovasi dalam dunia pendidikan, yang merupakan bentuk pengembangan dari model lama.
\end{abstract}

Kata kunci: model pembelajaran, konseptual, IPS

\title{
Pendahuluan
}

Secara garis besar, model pembelajaran merupakan pola yang di dalamnya terdapat strategi, teknik, metode, bahan, media, dan alat penilaian pembelajaran. Menurut trianto yang dimaksud dengan model pembelajaran adalah suatu perencanaan atau pola yang digunakan sebagai pedoman dalam merencanakan pembelajaran di kelas atau pembelajaran tutorial.

Menurut Chamalah,dkk, yang dimaksud dengan model merupakan cara atau tahapan metode pembelajaran yang digunakan dalam interaksi antara peserta didik dan pendidik untuk mencapai tujuan pembelajaran yang telah ditetapkan sesuai dengan materi dan mekanisme metode pembelajaran. jika dilihat mengenai proses pembelajaran, sejauh ini pendidikan masih di dominasi oleh pentingnya pengetahaun berbasis hafalan. Tak jarang ketika menjumpai proses pembelajaran di kelas, dimana masih berfokus pada guru sebagai learning center. Maka dari itu, diperlukan suatu pembaharuan model pembelajaran yang lebih berkembang dan memiliki nilai manfaat pada peserta didik. $^{1}$

Membahas mengenai pendidikan, hal ini sebanding dengan perkembangan zaman, dimana sistem pendidikan akan terus berkembang

\footnotetext{
${ }^{1}$ Muhamad Afandi, Evi Chamalah, and Oktarina Puspita Wardani, Model Dan Metode Pembelajaran Di Sekolah, Perpustakaan Nasional Katalog Dalam Terbitan (KDT), vol. 392 (Semarang: Perpustakaan Nasional Katalog Dalam Terbitan (KDT), 2013).
} 
menyesuaikan kebutuhan dari subjek pembelajaran baik dalam aspek budaya, sosial dan lingkungan. Pada tahun 2013, sistem pendidikan yang menggunakan kurikulum terpadu standart pendidikan (KTSP) di kembangkan lebih lanjut dan diganti dengan kurikum baru yaitu kurikulum 2013. Kurikulum 2013 merupakan kurikulum yang menggunakan pendekatan tematik integrative, yaitu sebuah kurikulum dengan mengintegrasikan berbagai kompetensi dari mata pelajaran ke dalam sebuah tema. Dimana dalam kurikulum 2013 pembalajarannya lebih ditekankan pada keaktifan siswa sebagai proses pemahaman materi.

IPS merupakan kependekan dari Ilmu Pengetahuan Sosial, yaitu sebuah bidang ilmu yang mempelajari bagaimana seorang individu berhubungan dengan individu lainnya baik secara kelompok kecil maupun secara kelompok besar. Selain itu, bidang ilmu ini mengkaji pola interaksi manusia, dimana manusia merupan makhluk sosial yang tidak bisa hidup sendiri. Integrasi konseptual dalam pembelajaran ini yaitu dapat menjadi refrensi model pembelajaran dan diharapkan agar peserta didik dapat memperoleh pemahaman dengan melalui komponen-komponen yang berada di dalam kontekstual

\section{Model Pembelajaran Kontekstual}

Kontekstual berasal dari kata "konteks" dalam Kamus Besar Bahasa Indonesia mengandung arti yaitu sesuatu yang berhubungan dengan konteks. Sedangkan konteks secara umum merupakan sesuatu yang ada hubungan dengan seatu kejadian. Model pembelajaran kontekstual merupakan salah satu model pembelajaran yang diterapkan dalam pendekatan tematik inegratif. Pada model pembelajaran ini lebih menekankan pembelajaran pada keterkaitan antara materi pelajaran dengan contoh kehidupan nyata. Adapun pengertian konseptual menurut beberapa ahli:

1. Menurut Kadir, model kontekstual merupakan sebuah konsep belajar siswa dengan prespektif dimana anak akan belajar lebih baik jika lingkungannya diciptakan secara ilmiah. Artinya tidak hanya mengerti apa yang disampaikan guru kepada peserta didik, tetapi mampu menerapkan kedalam lingkungannya. Sehingga peserta didik dapat bersemangat dalam memahami proses pembelajaran. ${ }^{2}$

\footnotetext{
${ }^{2}$ Abdul Kadir, "Konsep Pembelajaran Kontekstual Di Sekolah," Dinamika Ilmu 13, no. 1 (2013): 17-38.
}

Dirasah, Vol. 3, No.2, Agustus 2020 
2. Menurut Yustiana and Kusumadewi ${ }^{3}$, model kontekstual merupakan salah satu inovasi pembelajaran yang mengasumsikan peserta didik sebagai unsur aktif dalam pendidikan. Keaktifan peserta didik sangat dibutuhkan dalam pengembangan pemahaman, tetapi tidak hanya itu saja serta memahami materi dari lingkungannya.

3. Nurhadidalam Chamala $\mathrm{dkk}^{4}$, pembelajaran konstekstual merupakan konsep belajar dari guru yang menghadirkan dunia nyata kedalam kelas serta mendorong siswa untuk membuat hubungan antara pengetahuan dan kehidupan nyata.

4. Menurut Muslichdalam Chamala ${ }^{5}$, konsep kontektual membantu guru dalam mengaitkan antara materi pembelajaran dengan situasi kehidupan nyata serta mendorong sistwa untuk menghubungkan antara pengetahuan yang dimilikinya dan diterapkannya dalam kehidupan sehari-hari.

Dari pengertian dari beberapa ahli tersebut maka dapat disimpulkan bahwa pembelajaran kontekstual merupakan salah satu model pembelajaran yang bisa diterapkan oleh guru didalam proses pembelajaran. Dengan cara membawa contoh kehidupan nyata yang di integrasikan dengan ilmu pengetahuan, tujuannya supaya peserta didik mampu mengambil nilai-nilai pelajaran.

Masing-masing dari model pembelajaran memiliki komponen-komponen yang mendukung didalamnya. Model pembelajaran kontekstual terdapat tujuh komponen menurut Nurhadi dalam Chamala.,dkk, diantranya: (1) kontrukstivisme, (2) inqury (menemukan), (3) questioning (bertanya), (4) masyarakat belajar (learning community), (5) pemodelan (modelling), (6) reflection (refleksi), dan (7) Penilaian nyata.

Pertama kontrukstivisme, merupakan komponen yang dibangun oleh manusia sedikit demi sedikit. Hasilnya diperluas melalui konteks terbatas. Terbangunnya pemahaman ini menekankan pemahaman sendiri secara aktif, kreatif, dan produktif, berdasarkan pengetahuan terdahulu. Menurut Kadirterdapat dua point kontruktivisme dalam kontekstual yaitu: (1) membangun pemahaman pengalaman baru berdasarkan pada pengetahuan awal, (2) mengemas pembelajaran menjadi proses konstruksi bukan menerima

\footnotetext{
${ }^{3}$ Sari Yustiana and Rida Fironika Kusumadewi, "Pengembangan Bahan Ajar Modul Berbasis CTL Sebagai Bagian Dari Pengembangan SSP," Kontekstual 1, no. 2 (2020): 1-6.

${ }^{4}$ Afandi, Chamalah, and Wardani, Model Dan Metode Pembelajaran Di Sekolah. ${ }^{5}$ Ibid.
} 
pengetahuan. Jadi dalam pembelajaran kontrukstivisme dapat digambarkan bahwa siswa lahir dari pengetahuan kosong yang kemudian mendapatkan pengalaman awal dan dijadikan penegtahuan belajar. ${ }^{6}$

Kedua, inquiry (menemukan). Model ini merupakan suatu ide kompleks yang bermanfaat bagi banyak orang. Artinya, proses pembelajaran didasarkan pada pencarian dan penemuan melalui proses berfikir sistematis. Dalam pembelajaran ini langkah-langkah kegiatan meliputi merumuskan masalah, mengumpulkan data melalui observasi, menaganalisis dan menyajikan hasil dan tulisan, gambar laporan, bagan, table, dan karya lainnya ${ }^{7}$. Pembahasan inquiry lebih lanjut juga dibahas inquiry merupakan proses pengamatan menjadi pemahaman serta didalamnya siswa menggunakan ketrampilan berpikir kritis. ${ }^{8}$

Ketiga, bertanya (questioning). Dasar dari ilmu pengetahuan diawali dengan pertanyaaan. Menurut Afriani ${ }^{9}$ bertanya merupakan proses pembelajaran, dimana guru mendorong, membimbing, dan menilai kemampuan berpikir siswa. Pada komponen ini siswa belajar mengajukan pertanyaanpertanyaan tentang gejala-gejala yang ada. Komponen ini bisa menjadi bagian penting dalam inquiry.

Keempat, learning community (masyarakat belajar), yaitu kegiatan pembelajaran oleh sekelompok orang, dan sekelompok orang tersebut melakukan bekerja sama serta menggunakan aspek diskusi dalam bertukar ide dan pengalaman ${ }^{10}$. Artinya dalam komponen ini untuk bisa memperoleh pengetahuan dari orang lain, tidak berdasarkan teaching center, melainkan saling belajar (sharing) pada masing-masing anggota kelompok.

Kelima, pemodelan (modelling). Sebuah komponen pembelajaran yang menggunakan model untuk ditiru, dimana contoh ditampilkan dengan harapan peserta didik dapat mengaplikasikannya. Menurut Chamalah., dkk, modelling merupakan asas penting dalam pembelajaran konseptual. Sebab, melalui komponen ini, peserta didik dapat belajar langsung dan aplikasinya dalam sikap dan perilaku. ${ }^{11}$

\footnotetext{
${ }^{6}$ Kadir, "Konsep Pembelajaran Kontekstual Di Sekolah."

${ }^{7}$ Afandi, Chamalah, and Wardani, Model Dan Metode Pembelajaran Di Sekolah.

${ }^{8}$ Kadir, "Konsep Pembelajaran Kontekstual Di Sekolah."

${ }^{9}$ A. Afriani, "Pembelajaran Kontekstual (Contekstual Teaching Dan Learning) Dan Pemahaman Konsep Siswa.," Jurnal Al Muta'aliyah 1, no. 3 (2018).

${ }^{10}$ Kadir, "Konsep Pembelajaran Kontekstual Di Sekolah."

${ }^{11}$ Afandi, Chamalah, and Wardani, Model Dan Metode Pembelajaran Di Sekolah.
} 
Keenam, Refleksi (Reflektion). Komponen ini menekankan bagaimana carabefikir tentang yang baru dipelajari dan berpikir tentang pengalamn kemarin. Pengertian refleksi merupakan respon terhadap kejadian, aktifitas, atau pengetahuan terhadap apa yang baru saja diterima ${ }^{12}$. Dapat dikatakan bahwa komponen refleksi merupakan cara berfikir apa yang telah dipahami, kemudian mengenhubungkan dengan pengetahuan baru. Supaya refleksi dari pemahaman tersebut tidak mudah dilupakan, maka bisa melakukan kegiatan mencatat atau mendiskusikan bersama.

Ketujuh, Penilaian Autentik. Komponen ini merupakan kegiaatan pengumpulan informasi tentang apa yang dipahami peserta didik. Dengan kata lain komponen ini mengukur kemampuan pengetahuan dan ketrampilan peserta didik untudinlai kinerjanya. Pelaksanaannya bisa dilakukan sesudah dan sebelum proses pembelajaran. pada hakikatnya penilaian menurut Nurhadidalam Afandidkk., merupakan menilai apa yang seharusnya dinilai. ${ }^{13}$

Pada dasarnya hakikatnya pembelajaran kontekstual ini tentang timbal balik, menggunakan alat bantu, diskusi kelompok, cara menyampaikan informasi berdasarkan tempat dan waktu yang tersedia sesuai dengan kebutuhan peserta didik. Maka dari itu, kelebihan pembelajaran kontekstual dibandingkan dengan pembelajaran tradisonal diantarnya: (1) peserta didik memiliki peran aktif di dalamnya, (2) tidak hanya pada pengetahuan sepihak yang sudah ditetapkan, namun dalam pembelajaran ini peserta didik belajar dari orang lain, (3) diaplikasikan langsung dalam tingkah laku, (4) menjadikan kehidupan nyata sebagai bahan pembelajaran, (5) kontruksi ilmu pengetahuan berasal dari manusia itu sendiri bukan serangkaian teoritis absolut, (6) ketika peserta didik mampu memahami semuanya, ketrampilan dihasilkan dari pemahaman bukan latihan.

\section{Pembelajaran IPS Berbasis Kontekstual}

Pada dasarnya pembelajaran IPS berhubungan dengan kehidupan manusia yang terlibat dalam lingkunganya. Kajian bidang studi IPS mengenai manusia sebagai anggota masyarakat, mempunyai ruang lingkup mata pelajaran meliputi aspek-aspek sebagai berikut: manusia, tempat, dan lingkungan, sistem sosial dan budaya, ekonomi dan kesejahteraan.

\footnotetext{
${ }^{12}$ Afandi, Chamalah, and Wardani.

${ }^{13}$ Ibid.
} 
Dalam hal ini pandangan kontekstual tentang pembelajaran IPS adalah proses intelektual dimana peserta didik memperoleh pembelajaran dengan menerapkan contoh nyata kehidupan sehari-hari dan dipahami dengan apa yang sudah dipelajari. Sehingga dapat dikatakan pandangan kontekstual memfokuskan peserta didik untuk berperan aktif dalam proses pembelajaran, supaya materi yang dijadikan acuan pembelajaran dapat dipahami secara keseluruhan.

Dengan kerangka berfikir di atas, model kontekstual diyakini untuk di integrasikan dalam pembelajaran IPS. Tujuannya, dari hasil pembelajaran peserta didik dapat mengaplikasikan langsung dengan kehidupan nyata di lingkungannya dalam bentuk sikap, tingkah laku, pola piker dan lain sebagainya. Dilain sisi pembelajaran IPS berorenasi dengan kehidupan masyarakat. sehingga peserta didik selain memperoleh nilai pembelajaran juga dapat merefleksikannya untuk bisa dijadikan acuan bagaimana kompleksitas teori dengan realitas kehidupan.

\section{Penutup}

Kontekstual merupakan model pembelajaran inovatif yang bisa diterapkan oleh guru dalam proses pembelajaran. Hal tersebut berkaitan dengan bagaimana mengintegrasikan proses belajar di kelas dengan kenyataan dan hidup seharihari, sehingga darinya peserta didik dapat memperoleh hakikat dan makna hidup yang nyata.

\section{Daftar Pustaka}

Afandi, Muhamad, Evi Chamalah, and Oktarina Puspita Wardani. Model Dan Metode Pembelajaran Di Sekolah. Perpustakaan Nasional Katalog Dalam Terbitan (KDT). Vol. 392. Semarang: Perpustakaan Nasional Katalog Dalam Terbitan (KDT), 2013.

Afriani, A. "Pembelajaran Kontekstual (Contekstual Teaching Dan Learning) Dan Pemahaman Konsep Siswa." Jurnal Al Muta'aliyah 1, no. 3 (2018).

Kadir, Abdul. "Konsep Pembelajaran Kontekstual Di Sekolah.” Dinamika Ilmu 13, no. 1 (2013): 17-38.

Yustiana, Sari, and Rida Fironika Kusumadewi. "Pengembangan Bahan Ajar Modul Berbasis CTL Sebagai Bagian Dari Pengembangan SSP." 
Kontekstual 1, no. 2 (2020): 1-6.

Copyright (C) 2020Journal Dirasah: Vol. 3, No.2,Agustut 2020, p-ISSN: 2615-0212, e-ISSN; 2621-2838

Copyright rests with the authors

Copyright of Jurnal Dirasah is the property of Jurnal Dirasah and its content may not be copied oremailed to multiple sites or posted to a listserv without the copyright holder's express writtenpermission. However, users may print, download, or email articles for individual use. https://ejournal.iaifa.ac.id/index.php/dirasah 